\title{
TRANSVERSE AND LONGITUDINAL VARIATION IN WOODY RIPARIAN VEGETATION ALONG A MONTANE RIVER
}

\author{
Jonathan M. Friedman ${ }^{1}$, Gregor T. Auble ${ }^{2}$, Edmund D. Andrews ${ }^{1}$, Gwen Kittel ${ }^{3}$, \\ Richard F. Madole ${ }^{4}$, Eleanor R. Griffin ${ }^{1}$, and Tyler M. Allred ${ }^{5}$
}

\begin{abstract}
This study explores how the relationship between flow and riparian vegetation varies along a montane river. We mapped occurrence of woody riparian plant communities along $58 \mathrm{~km}$ of the San Miguel River in southwestern Colorado. We determined the recurrence interval of inundation for each plant community by combining step-backwater hydraulic modeling at 4 representative reaches with Log-Pearson analysis of 4 stream gaging stations. Finally, we mapped bottomland surficial geology and used a Geographic Information System to overlay the coverages of geology and vegetation. Plant communities were distinctly arrayed along the hydrologic gradient. The Salix exigua Nuttall (sandbar willow) community occurred mostly on surfaces with a recurrence interval of inundation shorter than 2.2 years; the Betula occidentalis Hooker (river birch) community peaked on sites with recurrence intervals of inundation between 2.2 and 4.6 years. The hydrologic position occupied by communities dominated by Populus angustifolia James (narrowleaf cottonwood) was strongly related to age of trees and species composition of understory shrubs. The fraction of riparian vegetation on surfaces historically inundated by the river decreased in the upstream direction from almost $100 \%$ near Uravan to $<50 \%$ along the South Fork of the San Miguel River. In upstream reaches much of the physical disturbance necessary to maintain riparian vegetation is provided by valley-side processes including debris flows, floods from minor tributaries, landslides, and beaver activity. Where valley-side processes are important, prediction of riparian vegetation change based on alterations of river flow will be incomplete.
\end{abstract}

Key words: Populus angustifolia, recurrence interval, inundation, tributary, flood, channel change, gradient analysis.

Pattern in riparian vegetation is strongly related to physical gradients created by the river. The 2 primary dimensions of these gradients are transverse, or perpendicular to the channel, and longitudinal, or along the length of the channel (Johnson and Lowe 1985, Malanson 1993, Bendix 1994). Many studies have focused on the transverse gradient at individual sites or river reaches. Moisture conditions go from hydric to mesic or xeric as distance and elevation increase away from the river. Variation in riparian vegetation away from the channel is correlated with decreasing intensity and frequency of flood disturbance (Auble et al. 1994, 1997), decreasing anoxia (Bedinger 1979), increasing drought stress (Zimmerman 1969), changes in fluvial-geomorphic surfaces (Hupp and Osterkamp 1985), and strong but inconsistent variation in sediment particle size (Robertson et al. 1978), nutrient availability (Day et al. 1988), and light availability (Menges and Waller 1983). Because correlations among these factors are high, the underlying cause of the pattern in vegetation at a site may be obscure. As a result, it is difficult to generalize a relationship derived at one site to another location along the same or a different river; likewise, it is difficult to predict the response of vegetation at a site to environmental change. Solutions to these problems require information on the variation of the vegetation-environment interrelationship over time and among sites (Chapin et al. 2000).

Longitudinal effects on riparian vegetation range from the scale of an entire watershed to the scale of an individual rock outcrop or debris fan (Rot et al. 2000). At the coarse scale, a suite of hydrologic, fluvial geomorphic, and climatic variables change predictably upstream. Along most western rivers, the upstream direction is associated with decreasing temperatures, increasing precipitation, decreasing potential evapotranspiration, increasing stream gradient, decreasing watershed size, decreasing stream

\footnotetext{
1U.S. Geological Survey, 3215 Marine Street, Suite E-127, Boulder, CO 80303

${ }^{2}$ U.S. Geological Survey, 2150 Centre Avenue, Building C, Fort Collins, CO 80526.

${ }^{3}$ NatureServe, 2400 Spruce Street, Suite 201, Boulder, CO 80302.

${ }^{4}$ U.S. Geological Survey, 3075 Fremont Street, Boulder, CO 80304

${ }^{5}$ Allred Restoration, Inc., 670 West 1725 North, Orem, UT 84057.
} 
discharge, and decreasing depth to bedrock (Patten 1998, Naiman et al. 2000). Riparian plant communities and individual species may be restricted to certain elevational ranges, but these ranges are often broader than those of species in adjacent uplands (Campbell and Dick-Peddie 1964, Hastings and Turner 1965, Campbell and Green 1968, Valenciano 1992). Floodplain extent often decreases in the upstream direction, and as a result, species associated with moist, finetextured sediments become less abundant upstream (Cowles 1901, Hupp 1986).

At a finer scale, tributary inputs and longitudinal variation in geology influence fluvial processes and riparian vegetation by controlling the delivery of water, woody debris, and sediment to the river (Gregory et al. 1991). Tributary junctions and valley constraints influence species occurrence by varying disturbance frequency, channel migration, and microhabitat diversity (Nilsson et al. 1989, 1994, Decamps and Tabacchi 1994, Scott et al. 1997, Benda et al. 2004). Longitudinal variation in depth to bedrock alters the interaction between surface and subsurface flows, influencing availability of nutrients and water to riparian plants (Zimmerman 1969, Naiman et al. 2000). Valleyside landslides and alluvial fans can provide a substrate for establishment of disturbancedependent species and may impede surface flow, thus promoting the development of wet meadows (Chambers et al. 2004).

Several investigations have considered the interaction of combined transverse and longitudinal gradients. At the watershed scale, the transverse gradient and separation between riparian and upland vegetation become less distinct upstream. Webb and Brotherson (1988) found that as elevation increased from $775 \mathrm{~m}$ to $2635 \mathrm{~m}$ along 3 streams in Utah, the transverse gradient became less distinct as more species in the riparian zone were shared with surrounding uplands. Similarly, Valenciano (1992) demonstrated that increasing elevation lessened distinctions between channel, terrace, and upland vegetation in a sample of riparian trees from 4 streams in southern Arizona spanning an elevational range from $677 \mathrm{~m}$ to $2948 \mathrm{~m}$. This trend reflects the increased precipitation and decreased evapotranspiration at higher elevations, which make high-elevation uplands more mesic than low-elevation uplands. Along tributaries of the Santa Clara River in California, Bendix (1994) showed that the transverse and longitudinal gradients were both important in explaining overall vegetation pattern, with neither gradient dominant. Wasklewicz (2001) found that measures of channel morphology and geometry that varied on both gradients were the most powerful determinants of riparian vegetation on cross sections from an elevational range of $1200 \mathrm{~m}$ to $2300 \mathrm{~m}$ in central Arizona. At a more local scale in the Okavango Delta of Botswana, longitudinal and transverse vegetation gradients mirror each other, apparently because sediment and nutrients are removed from the flow as water moves downstream or away from the channel (Ellery et al. 2003).

Relationships between vegetation and flow can be used to predict vegetation change following flow alteration (Franz and Bazzaz 1977, Auble et al. 1994, Primack 2000). For example, Auble et al. (1994) combined plot sampling of vegetation with hydraulic modeling in a 0.5 $\mathrm{km}$ reach of the Gunnison River to relate plant community occurrence to inundation duration along the transverse gradient. Assuming that these flow-vegetation relationships are invariant, the authors assessed how anticipated changes in the flow-duration curve would redistribute plant communities among their sampled plots. Because of the difficulty in collecting the large amount of topographic data necessary for hydraulic modeling, such analyses are usually limited to short river reaches and do not consider longitudinal changes in flow-vegetation associations.

The goal of this study was to quantify a relation between flow and woody riparian vegetation in order to explore both transverse and longitudinal vegetation patterns. This work is part of a research program developing quantitative methods to assess effects of flow regulation on riparian vegetation (Auble et al. 1994, 1997, 2005, Friedman and Auble 1999). Our study integrates 3 common activities along rivers that are typically carried out in isolation: inventory of riparian plant communities, mapping of surficial sediments, and hydraulic modeling.

\section{Study AREA}

The San Miguel River drains approximately $4000 \mathrm{~km}^{2}$ of the Rocky Mountains and Colorado Plateau in southwestern Colorado. From its headwaters above Telluride in the San Juan Mountains, the river flows northwest to its confluence with the Dolores River near 


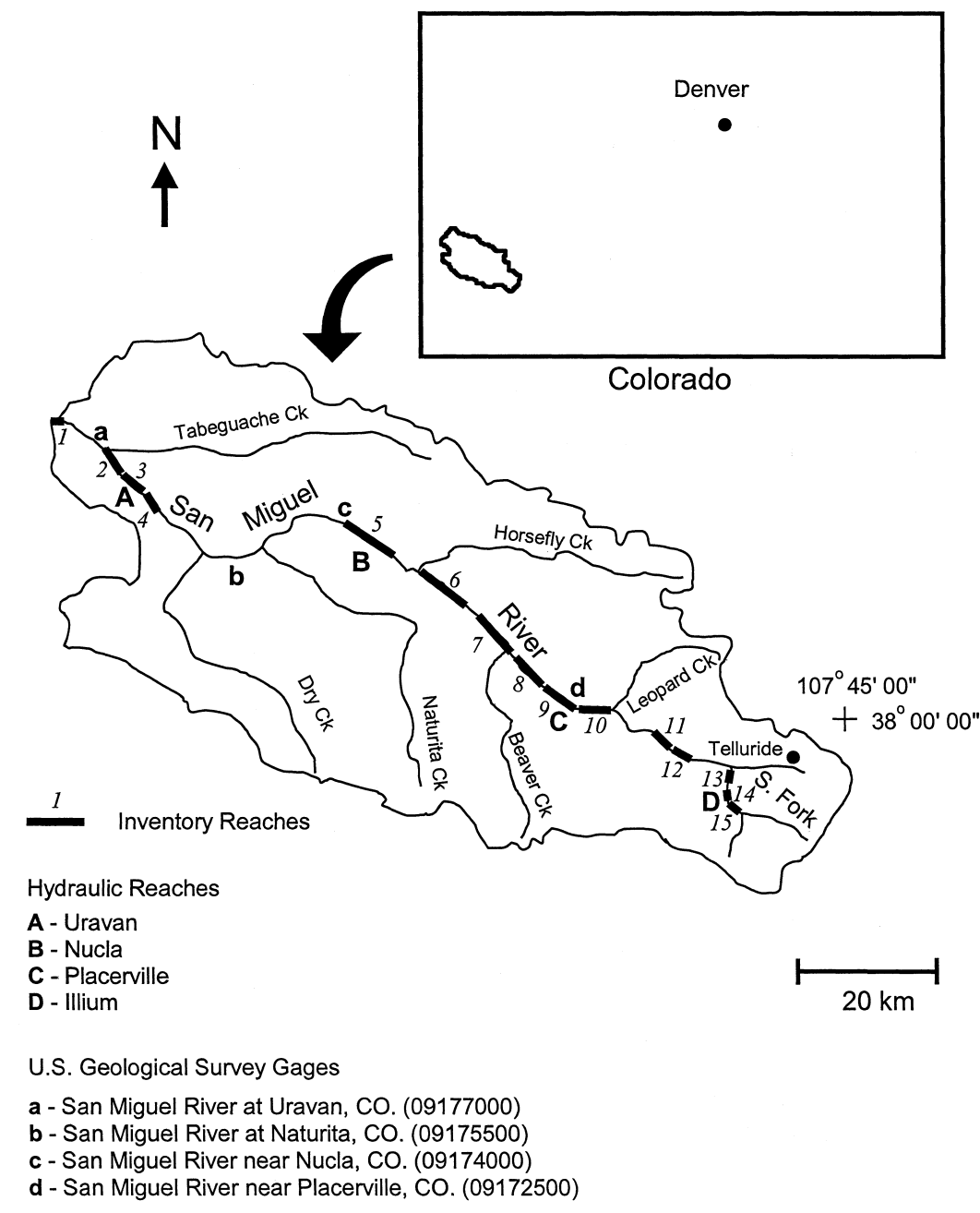

Fig. 1. San Miguel River, major tributaries, and watershed boundary in southwestern Colorado, USA, with locations of vegetation inventory reaches, hydraulic reaches, and U.S. Geological Survey gaging stations. Flow is to the northwest.

the Utah border (Fig. 1). Underlying bedrock trends from Tertiary volcanic rocks in the headwaters to sandstone and shale of Pennsylvanian to Jurassic ages downstream (Williams 1964). Lateral migration along much of the San Miguel River is constrained by bedrock walls. Our study area was the $134-\mathrm{km}$ river section from the mouth of the San Miguel River upstream to the headwaters of the South Fork (Fig. 1). In this watershed, temperature decreases and precipitation increases with increasing elevation. At Uravan, near the river mouth (gage a in Fig. 1), elevation is $1530 \mathrm{~m}$, annual precipitation is $320 \mathrm{~mm}$, average daily maximum temperature in July is $34.9^{\circ} \mathrm{C}$, and average daily minimum temperature in January is $-9.2^{\circ} \mathrm{C}$.
At Telluride near the upstream end of the study area, elevation is $2670 \mathrm{~m}$, annual precipitation is $595 \mathrm{~mm}$, average daily maximum temperature in July is $25.1^{\circ} \mathrm{C}$, and average daily minimum temperature in January is $-16.8^{\circ} \mathrm{C}$ (Western Regional Climate Center, climate normals for 1971-2000). The San Miguel is one of the last relatively unregulated rivers remaining in the Colorado River basin. The river has no large reservoirs or major diversions, and the flow regime is essentially natural. Parts of the bottomland, however, have been altered by placer mining, gravel mining, storage and disposal of mine tailings, highway construction, residential development, agricultural cultivation, and livestock grazing. Sites where the 
vegetation has been greatly altered by recent human disturbance were avoided in this study.

\section{Methods}

Our approach is an application of directgradient analysis (Whittaker 1956, 1967, Franz and Bazzaz 1977, Bedinger 1979, Jongman et al. 1987, Auble et al. 1994, 1997), which describes the position of vegetation along environmental gradients. Gradients examined included the recurrence interval of inundation and distance upstream from the mouth of the San Miguel River. We focused on the influence of high flows because flood-dependent species are dominant along the San Miguel and because most of the woody species occur outside the zone inundated by moderate flows.

Following the protocol of Kittel et al. (1999), we mapped the woody riparian vegetation in 15 inventory reaches along the San Miguel River, including most of the riparian land in excellent or pristine condition (Fig. 1). These 15 reaches included 260 ha and 58 river $\mathrm{km}$, or $43 \%$ of the study area. Maps were drawn in the field on enlargements of U.S. Geological Survey 7.5-minute topographic maps with the aid of aerial photographs. Within the 15 reaches, the riparian zone was divided into polygons, each occupied by 1 of 72 vegetation types defined on the basis of dominant woody species (Kittel et al. 1999). We mapped 699 polygons, ranging in area from $40 \mathrm{~m}^{2}$ to $66,376 \mathrm{~m}^{2}$ $\left(\right.$ median $\left.=1432 \mathrm{~m}^{2}\right)$. The mapped area began at the channel's edge and extended from the channel to the highest fluvial surface occupied by obligate riparian species. At a point representative of the mean elevation within each delineated polygon we used a rod and level to measure height above the lowest perennial vegetation (active channel shelf reference level of Hedman and Osterkamp 1982).

Most of the 72 vegetation types did not occur frequently enough to define a relationship between occurrence and flow. Therefore, we grouped these types into communities using key dominant overstory and understory species. For example, the Populus angustifolia / Salix exigua community includes all types with $P$. angustifolia James (narrowleaf cottonwood) as an overstory dominant and S. exigua Nuttall (sandbar willow) as an understory dominant. The S. exigua community includes all types dominated by S. exigua with no overstory.
In our investigation of the relationship between vegetation and flood recurrence interval, we focused on the 6 communities that were abundant in most inventory reaches: $S$. exigua, 148 polygons covering $19.1 \mathrm{ha}$; Alnus incana (L.) Moench subsp. tenuifolia (Nuttall) Breitung (alder), 92 polygons covering $12.2 \mathrm{ha}$; Betula occidentalis Hooker (river birch), 104 polygons covering 15.8 ha; $P$. angustifolia / S. exigua, 62 polygons covering 22.3 ha; $P$. angustifolia / A. incana, 102 polygons covering 57.7 ha; and P. angustifolia / B. occidentalis, 24 polygons covering 14.0 ha. For occurrences of all vegetation types dominated by $P$. angustifolia (253 polygons covering $164 \mathrm{ha}$ ), we characterized the cottonwoods as young, mature, or mixed-age. This allowed us to relate cottonwood age class to flood recurrence interval.

We made detailed investigations of $4 \mathrm{hy}$ draulic reaches along the San Miguel, each within 1 of the 15 inventory reaches (Fig. 1). The Uravan hydraulic reach is upstream of the confluence with Tabeguache Creek, near U.S. Geological Survey gage 09177000 (San Miguel River at Uravan, Colorado), which has a drainage area of $3882 \mathrm{~km}^{2}$. The Nucla hydraulic reach is upstream of gage 09174000 (San Miguel River near Nucla, Colorado); its drainage area covers $1681 \mathrm{~km}^{2}$. The Placerville hydraulic reach is at gage 09172500 (San Miguel River near Placerville, Colorado), with a drainage area of $798 \mathrm{~km}^{2}$. The Illium hydraulic reach, on the South Fork San Miguel River at Illium Valley, upstream of the town of Illium, has a drainage area of $122 \mathrm{~km}^{2}$. These hydraulic reaches were chosen to represent the range of sediment transport conditions along the river, to take advantage of proximity to long-term U.S. Geological Survey stream gages, and to overlap with the areas of mapped vegetation. In addition, the hydraulic reaches were located to minimize the occurrence of features that can lead to error in hydraulic models, including supercritical flow, sharp bends, and sudden changes in width. At the Illium, Nucla, and Uravan reaches (Fig. 1), we made a detailed topographic survey of a $0.5-\mathrm{km}$ section of the river and flood plain, interpolated a series of cross sections, and used a 1-dimensional stepbackwater hydraulic model to determine the stage over a range of discharges (Allred and Andrews 2000). The hydraulic models were calibrated by measurements of stage at low and moderate discharge. A single stage-discharge 
relation was developed for each reach by averaging the relations for all modeled cross sections and fitting an exponential curve to the average values. At the Placerville reach (Fig. 1), we used the stage-discharge relation developed by the U.S. Geological Survey for the stream gage at that site (San Miguel River near Placerville, 09172500). To extend the stage-discharge relations to the river as a whole, we assigned each of the 15 inventory reaches to 1 of the hydraulic reaches: inventory reaches $1-4$ to Uravan, inventory reaches 5-6 to Nucla, inventory reaches 7-12 to Placerville, and inventory reaches $13-15$ to Illium.

Our direct-gradient analysis was based on the recurrence interval of inundation for polygons in the riparian zone. First, the discharge necessary to inundate a polygon (inundating discharge) was determined by comparing its height above the lower limit of perennial vegetation to the appropriate stage-discharge relation. Then the recurrence interval of inundation for the polygon was determined using the relation between discharge and recurrence interval.

We surveyed the elevation of the lowest extent of perennial vegetation at several points along the Uravan hydraulic reach. On average this level was inundated $26 \%$ of the time (i.e., 95 days of inundation per year; Friedman and Auble 1999). On the basis of this result at Uravan, we assumed that the lowest extent of perennial vegetation occurred at approximately the $26 \%$ flow exceedance level in all inventory reaches. Stage was then expressed relative to the lowest extent of perennial vegetation, making it possible to determine the discharge necessary to inundate each mapped vegetation polygon.

At Uravan, Nucla, and Placerville, we applied Log-Pearson type III analysis to the record of peak instantaneous annual discharge from a nearby stream gage to determine the discharge at recurrence intervals ranging from 1.005 to 500 years. The periods of record for these gages ranged in length from 9 to 59 years. For inventory reach 1 , we used the relationship between recurrence interval and discharge at the Uravan gage. For inventory reaches 2, 3, and 4, the record at Uravan was adjusted to remove the discharge of Tabeguache Creek, which enters the San Miguel just downstream of inventory reach 2 (Fig. 1; Allred and Andrews 2000). For inventory reaches 5-12 we estimated the discharge for a given recurrence interval using linear interpolation and extrapolation based upon the distance along the river between Nucla and Placerville. Because there was no stream gage near the Illium hydraulic reach, we used a regional relation based on topographic relief and mean annual precipitation (Surian and Andrews 1999) to estimate discharge at recurrence intervals ranging from 1.25 to 100 years. We applied these results to inventory reaches $13-15$. To develop a continuous relationship between recurrence interval and discharge at each inventory reach, we used a regression of the form

$$
\ln \left(\mathrm{R}_{\mathrm{I}}-\mathrm{l}\right)=\mathrm{a} * \mathrm{Q}+\mathrm{b} * \ln (\mathrm{Q})+\mathrm{c},
$$

where $\ln$ is the natural logarithm, $\mathrm{R}_{\mathrm{I}}$ is recurrence interval in years, $Q$ is discharge in $\mathrm{m}^{3}$. $\mathrm{s}^{-1}$, and $\mathrm{a}, \mathrm{b}$, and $\mathrm{c}$ are constants.

It was also necessary to consider the geomorphic and ecological effects of a flood resulting from failure of dams on Middle Reservoir and Trout Lake on the South Fork San Miguel River on 5 September 1909. All that is known about this flood is that the duration was short and the peak discharge was roughly estimated as $283 \mathrm{~m}^{3} \cdot \mathrm{s}^{-1}$ at Placerville (Wells 1954). We did not include the dam-break flood in our calculations of recurrence interval because it was not part of the population of natural high flows and because the longitudinal variation in peak discharge of this event is unknown. However, because a flood of this magnitude is likely to have influenced the vegetation, we calculated the area of mapped vegetation inundated by the estimated $283 \mathrm{~m}^{3} \cdot \mathrm{s}^{-1}$ magnitude of the dam-break flood but not by historic natural flows-defined as flows with a recurrence interval $<150$ years, the approximate life span of stems of the dominant species, $P$. angustifolia.

In order to relate plant community occurrence to geomorphic processes, we mapped landforms along the San Miguel River in 4 reaches centered on the 4 hydraulic reaches. Maps were drawn using mylar overlays on aerial photographs with an image scale of 1:40,000 or larger taken on the following dates: Uravan, 6 June 1982; Nucla, 8 June 1982; Placerville, 27 August 1965; and Illium, 24 September 1988. We divided the bottomland into polygons occupied by the following landforms: present channel, Quaternary alluvium (floodplain and low terraces of the San Miguel and 
South Fork San Miguel River inundated by natural flows during the historic period), Pleistocene terrace (no longer inundated by the river), Quaternary fan (deposited by streams and debris flows at the mouths of tributaries), Quaternary colluvium (deposited chiefly by mass wasting of hillslopes by processes other than landsliding), Quaternary landslide (early Holocene or late Pleistocene in age), beaver impoundment (organic-rich sediment deposited behind beaver dams along tributaries within the San Miguel River bottomland), catastrophic flood deposit (apparently deposited by the dam-break flood of 1909), and artificial fill (e.g., from highway construction). Overlays were scan-digitized and rectified to U.S. Geological Survey 7.5-minute topographic maps using the ARC/INFO Geographic Information System (GIS). Maps of landforms and vegetation were overlain within ARC/INFO. Valley lengths and area (excluding channel) of the reaches with landform and vegetation coverage were $7.83 \mathrm{~km}$ and 52.9 ha at Uravan, 6.02 $\mathrm{km}$ and 57.7 ha at Nucla, $7.40 \mathrm{~km}$ and $35.3 \mathrm{ha}$ at Placerville, and $3.37 \mathrm{~km}$ and $27.3 \mathrm{ha}$ at Illium. Within each of these 4 areas, we calculated the total area of each landform type.

We used the GIS to relate channel change to cottonwood reproduction. At Uravan, Nucla, and Placerville, we prepared 3 additional coverages consisting of the channel location in the 1960s (29 June 1960 at Uravan, 3 October 1965 at Nucla, and 27 August 1965 at Placerville), in 1982 (6 June at Uravan, 8 June at Nucla, and 9 June at Placerville), and in 1993 (2 July at Uravan and Nucla and 14 September at Placerville). The Illium reach was excluded from this part of the analysis because there were no available photos from the early 1980s. We subdivided the areas with overlapping landform and vegetation coverage into $1-\mathrm{km}$ subreaches. Within each subreach, we related the area of former channel (total area that was channel in the 1960s or 1982 but not in 1993) to the quantity $\mathrm{Y}+\mathrm{M} / 2$, where $\mathrm{Y}$ is the area of cottonwood age class "young" and $\mathrm{M}$ is the area of cottonwood age class "mixed age."

\section{REsults AND Discussion}

The San Miguel watershed shows the typical pattern of decreasing discharge in the upstream direction for a given flow recurrence interval (Fig. 2); however, the hydrologic pro-

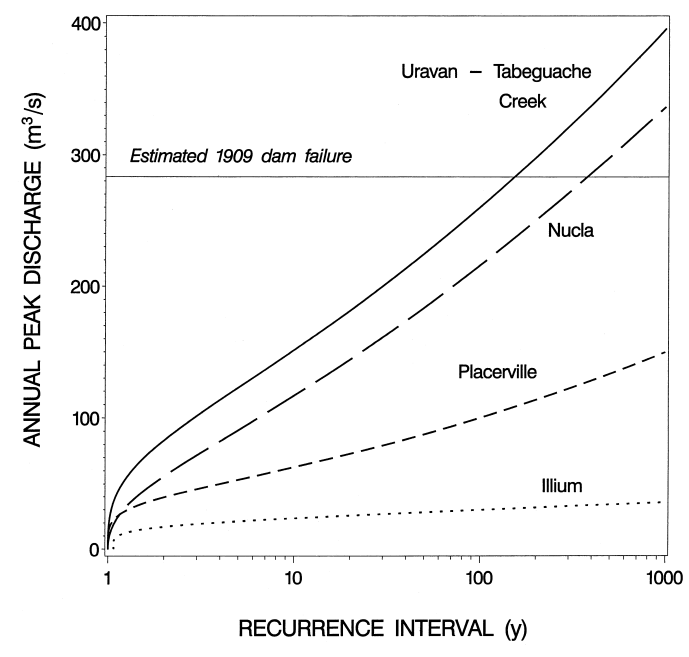

Fig. 2. Peak instantaneous annual discharge vs. recurrence interval for 4 hydraulic reaches. The Uravan curve is based on the Uravan gage with the influence of Tabeguache Creek removed; the Nucla curve is based on the Nucla gage; the Placerville curve is based upon the Placerville gage; and the Illium curve is based upon a regional relation. The horizontal line indicates the estimated discharge resulting from failure of dams at Middle Reservoir and Trout Lake on 5 September 1909.

cesses responsible for flooding vary longitudinally. The intensity of summer monsoonal thunderstorms decreases with increasing elevation (Jarrett 1990). Upstream at Placerville, snowmelt has produced most of the annual peak instantaneous discharges, while downstream at Uravan, summer rainfall has produced 3 of the 10 largest flows including the flood of record in 1970 (Fleener 1997). Because the discharge of a given recurrence interval decreases strongly upstream (Fig. 2), while the height of a given discharge does not change progressively (Fig. 3), the height of a surface with a given recurrence interval of inundation also decreases upstream. Unit discharges of the natural peak flows along the San Miguel River are roughly half the magnitude of flows of the same recurrence interval in streams draining the foothills of the Rocky Mountains in eastern Colorado, which are subject to more intense rainfall (Follansbee and Sawyer 1948, Fleener 1997). The estimated peak instantaneous discharge of the dam-break flood of $1909\left(283 \mathrm{~m}^{3}\right.$ $\cdot \mathrm{s}^{-1}$ ) was 1.1 times the 100-year flood at Uravan, 1.3 times the 100-year flood at Nucla, 2.8 times the 100-year flood at Placerville, and 9.5 times the 100-year flood at Illium (Fig. 2). 


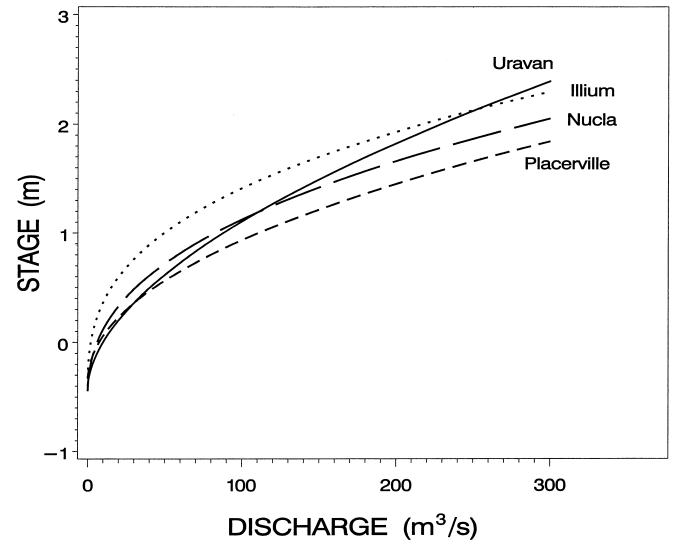

Fig. 3. Stage-discharge relations for the hydraulic reaches. Stage is the height above the estimated lower limit of perennial vegetation.

Riparian communities along the San Miguel River are dominated by cottonwood (Populus spp.). Seventy-three percent of the mapped riparian area was identified as being among the 31 community types dominated by cottonwood, mostly the montane species Populus angustifolia. The lowland species Populus deltoides Marshall subsp. wislizenii (Watson) Eckenwalder (Rio Grande cottonwood) is a co-dominant as far upstream as the 4 th inventory reach (river $\mathrm{km} \mathrm{20)}$. Other important dominants are Alnus incana, Betula occidentalis, Salix exigua, and Picea pungens Engelmann (blue spruce). Salix geyeriana Andersson (Geyer willow) is common upstream along the South Fork. The shrubs Rhus trilobata Nuttall (skunkbrush sumac), Forestiera pubescens Nuttall (New Mexican privet), Shepherdia argentea (Pursh) Nuttall (silverberry), and Cornus sericea L. (red-osier dogwood) are also common along the San Miguel River.

Plant communities were distinctly arrayed along the transverse hydrologic gradient even when data from all sites were pooled (Fig. 4). Relative positions of the different communities along the transverse gradient were consistent with ecological requirements of the dominant species. Closest to the water was the $S$. exigua community. Most occurrences of this community were on surfaces with a recurrence interval shorter than 2.2 years (Fig. 4). A smallseeded species with high requirements for moisture and light, S. exigua has the ability to form abundant sprouts from roots and buried stems. This vegetative reproduction allows it to survive and spread in the heavily disturbed zone near the channel, and its numerous small seeds are dispersed quickly by wind and water to surfaces recently formed by flood disturbance. However, because it is a poor competitor for light and moisture it does not persist on older, drier, or shaded sites (Auble et al. 1994, Hansen et al. 1995, Friedman et al. 1996). For these reasons, S. exigua is restricted to surfaces with a short recurrence interval of inundation (Fig. 4). A low-elevation species, S. exigua becomes less important on the San Miguel River upstream of Leopard Creek (2220 m; Fig. 1).

Alnus incana and B. occidentalis, like S. exigua, typically colonize sites recently disturbed by the river. Intermediate in size between S. exigua and Populus angustifolia, these large shrubs can persist on sites with a longer recurrence interval of inundation than those occupied by S. exigua (Fig. 4). Their relative inability to form root sprouts may limit their occurrence on sites with the shortest recurrence intervals of inundation. As a result these species were dominant at intermediate recurrence intervals, above sites occupied by sandbar willow. Communities dominated by $A$. incana and B. occidentalis reached their peak in relative abundance on sites with recurrence intervals of inundation between 2.2 and 4.6 years (Fig. 4).

Populus angustifolia, a member of the same family as S. exigua (Salicaceae), has a similar ability to colonize recently disturbed sites and similar requirements for light and moisture. Its deep roots, however, allow it to persist on sites high above the channel, and its tall stem allows it to compete for light for many decades after a disturbance. The position of the cottonwood-dominated communities along the recurrence interval axis was drier than the position of the most important associated species. For example, the P. angustifolia / S. exigua community occurred at longer recurrence intervals than the S. exigua community. This difference reflects the fact that $S$. exigua can maintain dominance over cottonwood only at hydric, frequently disturbed sites. In the same way, the $P$. angustifolia / Alnus incana community occurred at longer recurrence intervals than the A. incana community, and P. angustifolia / Betula occidentalis occurred at longer recurrence intervals than B. occidentalis (Fig. 4). 

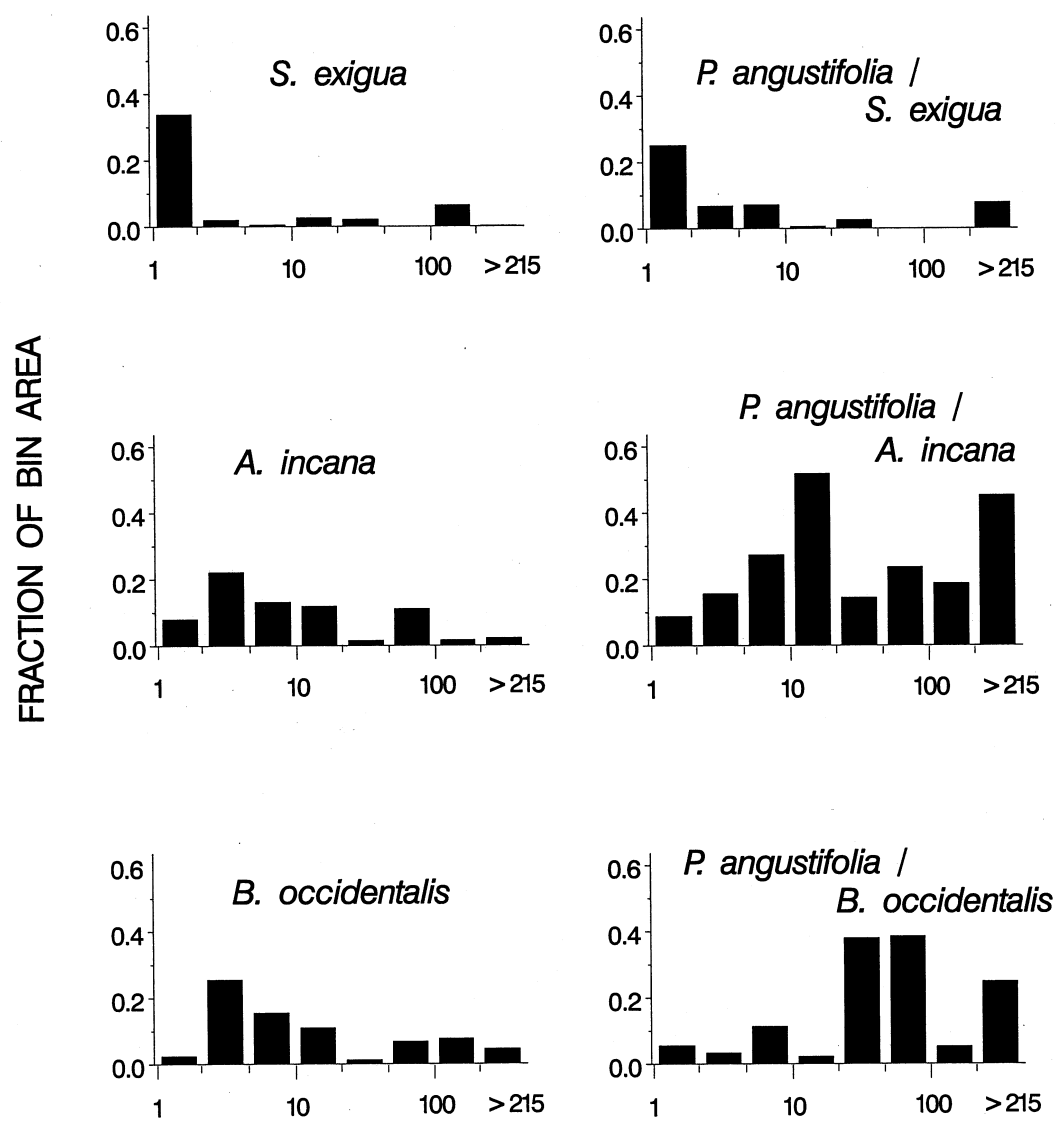

RECURRENCE INTERVAL (y)

Fig. 4. Fraction of area occupied by communities as a function of recurrence interval of inundation. The height of each bar is the total area of polygons occupied by occurrences of the specified community within the specified bin of recurrence interval, divided by the total area of all polygons within that bin. The histogram for each community includes data only from the range of inventory reaches in which that community occurred. Full names of species used in community names are Salix exigua Nuttall, Alnus incana (L.) Moench subsp. tenuifolia (Nuttall) Breitung, Betula occidentalis Hooker, and Populus angustifolia James.

The age of $P$. angustifolia trees was strongly related to position along the recurrence interval axis. Patches of young $P$. angustifolia occurred mostly at recurrence intervals of inundation shorter than 22 years, mature $P$. angustifolia occurred mostly at recurrence intervals of inundation longer than 22 years, and mixed ages occurred across a broad range of recurrence intervals (Fig. 5).

The distribution of different-aged cottonwood stands along the transverse hydrologic gradient mirrored the distribution of cottonwood-dominated community types. Young $P$. angustifolia occurred on sites with a short recurrence interval of inundation and were commonly associated with S. exigua, A. incana, or B. occidentalis (Figs. 4, 5). Mature stands of $P$. angustifolia occurred on rarely inundated sites and were often associated with $A$. incana or B. occidentalis, but not S. exigua (Figs. 4, 5). There are 2 probable reasons for this pattern. First, there is a successional process in which $P$. angustifolia is established on low, recently deposited surfaces in association with S. exigua, A. incana, or B. occidentalis. As these surfaces age, sediment is deposited, surfaces become drier, P. angustifolia matures, and S. exigua drops out. Second, cottonwood may become 


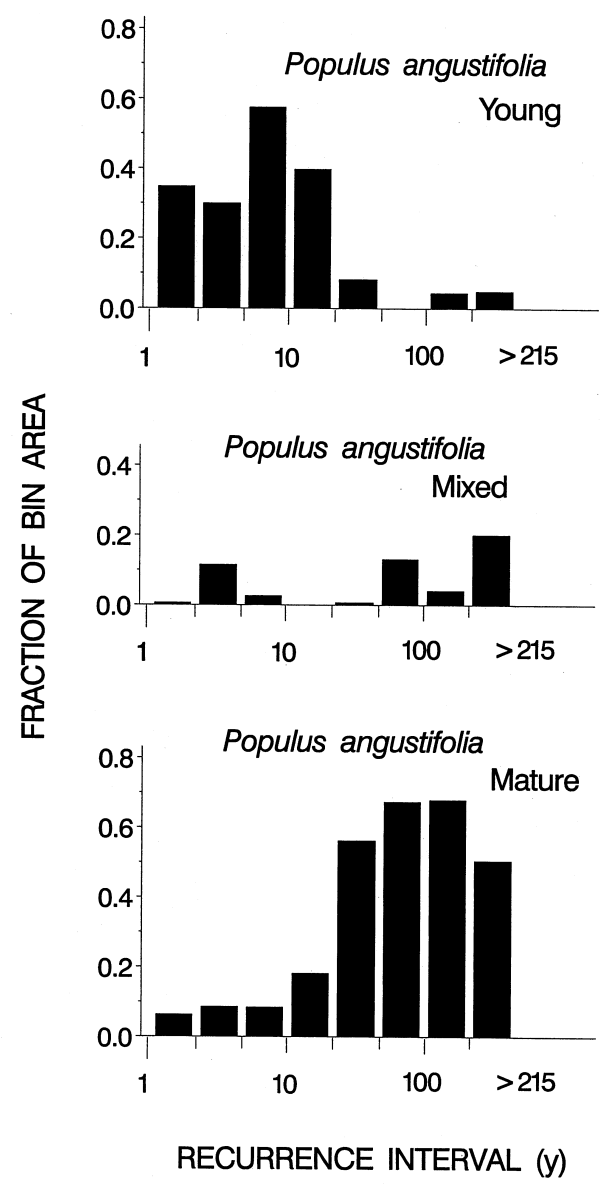

Fig. 5. Fraction of area occupied by age classes of Populus angustifolia James as a function of recurrence interval of inundation. Axes were constructed as in Figure 4.

established high above the channel following large floods (Scott et al. 1997). Since no major floods have occurred along the San Miguel River since the 1909 dam break, all such stands of $P$. angustifolia are now mature, and the associated vegetation reflects the recent absence of flood disturbance and the relatively dry surface.

The proportion of riparian vegetation on surfaces inundated by the San Miguel River decreased upstream (Fig. 6). In all inventory reaches from river $\mathrm{km} 1.4$ to 65.2 , at least $88 \%$ of the vegetation mapped as riparian occurred on surfaces inundated by flows with a recurrence interval shorter than 150 years (Fig. 6). Upstream of river $\mathrm{km} 65.2$, the proportion of riparian vegetation inundated by the 150 -year flood declined, falling below $4 \%$ at river $\mathrm{km}$

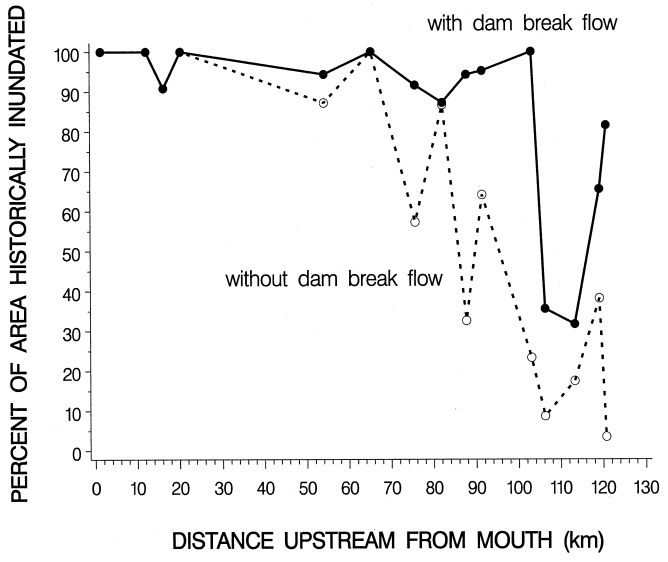

Fig. 6. Percent of mapped riparian vegetation that has been inundated in the last 150 years vs. river distance upstream from the confluence with the Dolores River. Each point summarizes the data from a single inventory reach. The dashed line includes only natural flows; the solid line also includes the dam-break flood of 1909.

120.7. When the dam-break flood was included, this decline did not begin until upstream of river $\mathrm{km} 103.0$ (Fig. 6).

The longitudinal trend in the relation between recurrence interval of inundation and community occurrence varied among communities (Fig. 7). The range of recurrence intervals occupied by the $S$. exigua community was stable throughout the study area. This community was restricted to wet sites with short recurrence intervals of inundation in all inventory reaches. On the other hand, the $P$. angustifolia community extended to longer recurrence intervals in the upstream direction. In the lower $30 \mathrm{~km}$ of the river, $P$. angustifolia was essentially restricted to surfaces that have recurrence intervals of inundation shorter than 150 years. Upstream of river $\mathrm{km} \mathrm{70,} \mathrm{P.} \mathrm{angustifo-}$ lia commonly occurred on surfaces with recurrence intervals longer than 150 years. These surfaces are not known to have been inundated by natural flows from the San Miguel. The response of the A. incana and B. occidentalis communities was intermediate between those of S. exigua and P. angustifolia (Fig. 7).

The extension of some communities above the zone of inundation along upstream reaches of the San Miguel River can be explained in part by greater water availability; rainfall increases and evaporation decreases with increasing elevation. The greater moisture availability allows riparian plants to survive in the absence 

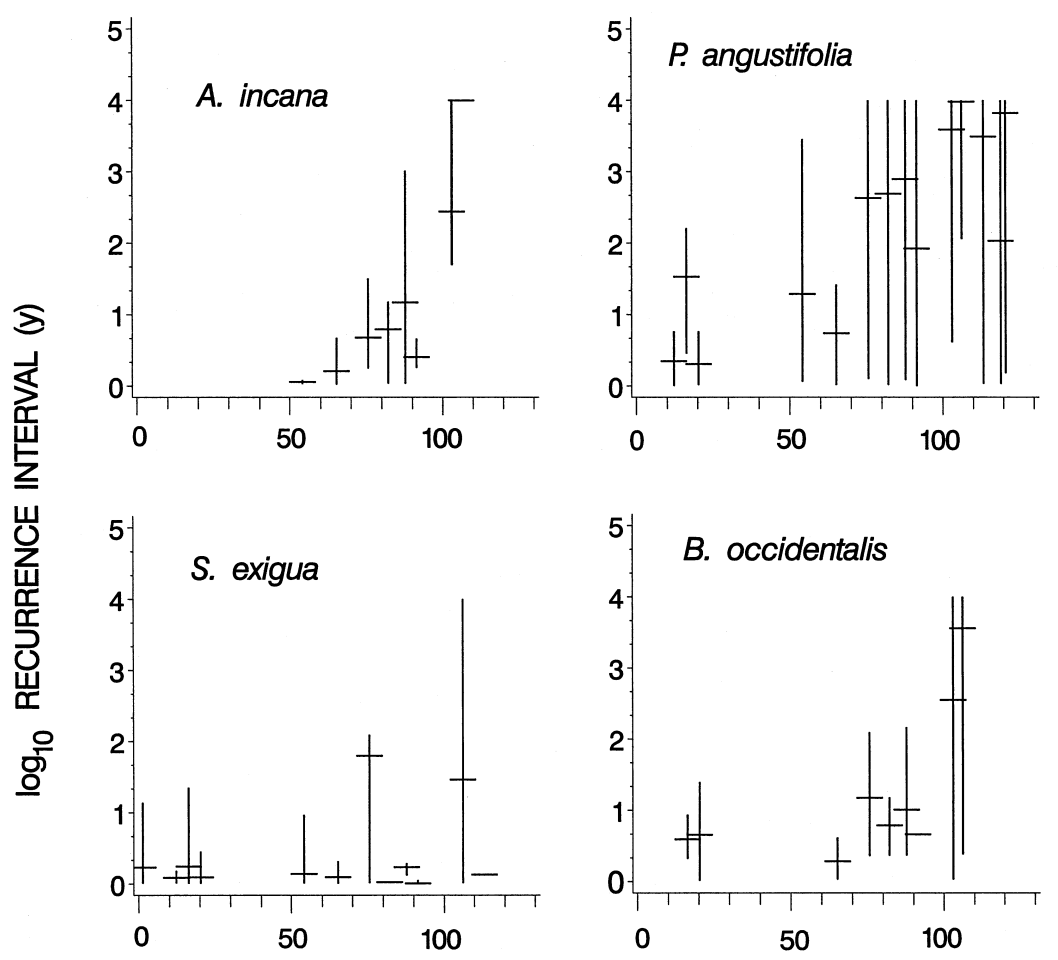

DISTANCE UPSTREAM FROM MOUTH $(\mathrm{km})$

Fig. 7. Recurrence interval of inundation of polygons occupied by selected communities vs. distance upstream from the confluence with the Dolores River. Each cross summarizes data from 1 inventory reach. Vertical lines indicate the range of recurrence intervals for a community at an inventory reach. Short horizontal lines are the area-weighted mean. Full names of species used in community names are Salix exigua Nuttall, Alnus incana (L.) Moench subsp. tenuifolia (Nuttall) Breitung, Betula occidentalis Hooker, and Populus angustifolia James.

of a surface water subsidy from the river (Webb and Brotherson 1988). To the extent that riparian vegetation depends upon physical disturbance, however, causes of disturbance other than natural mainstem floods must be adequate for riparian plant establishment and survival in upstream reaches. These agents of disturbance include floods and debris flows from small tributaries, the dam-break flood of 1909, and beaver dams on low terraces. Such disturbances are apparently frequent enough to allow the $P$. angustifolia community, but not the $S$. exigua community, to occur on surfaces that have not been historically flooded by natural flows of the San Miguel River.

Our maps of geomorphic surfaces along the San Miguel River showed that deposits from valley-side processes make up a larger proportion of the area occupied by riparian vegeta- tion at Illium and Placerville than downstream at Nucla and Uravan. Flood plains and terraces deposited by natural flows of the San Miguel River made up $87 \%$ and $98 \%$ of the area occupied by riparian vegetation in the Uravan and Nucla reaches, but only $64 \%$ and $53 \%$ of the area occupied by riparian vegetation in the Placerville and Illium reaches (Table 1). Important valley-side deposits included tributary fans from floods and debris flows, landslide deposits, and beaver ponds (Table 1). The dam-break flood of 1909 formed terraces across $11 \%$ of the area occupied by riparian vegetation in the Illium reach (Table 1). This evidence suggests that the dam-break flood is an important, but not dominant, factor explaining the occurrence of riparian vegetation above the level of historic inundation at Illium. Ages of $P$. angustifolia from a site near the Illium reach (G. 
TABLE 1. Relative area occupied by 8 geomorphic surface types at 4 locations along the San Miguel River, Colorado. Values are percentages of the area occupied by riparian vegetation.

\begin{tabular}{lcccc}
\hline Landform & Uravan & Nucla & Placerville & Illium \\
\hline Quaternary alluvium & 86.9 & 97.9 & 64.2 & 52.8 \\
Quaternary fan & 12.9 & 1.5 & 30.4 & 6.8 \\
Pleistocene terrace & 0.2 & 0 & 0 & 0 \\
Quaternary colluvium & 0 & 0 & 0.9 & 0 \\
Quaternary landslide & 0 & 0.4 & 0 & 17.1 \\
Beaver impoundment & 0 & 0 & 0 & 12.0 \\
Catastrophic flood deposit & 0 & 0 & 0.5 & 11.3 \\
Artificial fill & 0 & 0 & & 0 \\
\hline
\end{tabular}

Auble unpublished data) did not show a large proportion of the population dating to 1909 or the subsequent decade.

The abundance of valley-side deposits in the Placerville and Illium reaches resulted from the steep terrain, the presence of weak marine shale containing expansive clay minerals, and the limited sediment transport capacity of the upper San Miguel and South Fork San Miguel Rivers. Debris flows have increased the height of fluvial deposits by temporarily damming the San Miguel River in the Illium reach as recently as the interval between our aerial photographs in 1965 and 1988. Chapin et al. (2000) also observed riparian vegetation at unusually long recurrence intervals of inundation along a recently incised stream in Oregon.

Cottonwood reproduction along the San Miguel River is associated with channel migration. The area of young cottonwoods in 22 of the $1-\mathrm{km}$ subreaches is correlated with the rate of channel migration (Fig. 8). This relationship is stronger in the downstream reach (Uravan, $r=0.92$ ) than in the upstream reaches (Placerville and Nucla, $r=0.69$ ). Cottonwood seedlings require a bare, moist surface for establishment. At Uravan such surfaces are essentially restricted to portions of the former channel bed, and variation in the abundance of young cottonwoods on the $1-\mathrm{km}$ scale is mostly related to factors promoting or restricting channel migration. At Placerville and Nucla, processes other than channel migration also appear to be providing surfaces suitable for cottonwood reproduction. Specifically, young cottonwoods occur on bars that have been disturbed by floods or other factors but have not been part of the channel bed in recent decades. This longitudinal contrast is consistent with the increasing influence of valley-side processes in the upstream direction. Also important may be the fact that Uravan was dominated by $P$. deltoides, a species that reproduces almost entirely from seeds, while sites further upstream were dominated by $P$. angustifolia, which reproduces by both root sprouts and seeds (Gom and Rood 1999). Dependence of $P$. deltoides reproduction on channel migration has been documented along a variety of channel types in the western United States (Bradley and Smith 1986, Friedman and Lee 2002).

In the upper Klamath Basin, Oregon, the upper limit of riparian plant communities along the transverse gradient is typically between the levels of the 3- and 7-year recurrence intervals of inundation, but it can extend above the level of the 25-year recurrence interval where bed elevation has fluctuated in the past or where groundwater is an important moisture source (Chapin et al. 2000). Along the San Miguel River, the S. exigua, A. incana, and $B$. occidentalis communities were all most frequent between the levels of the 3- and 7-year recurrence intervals of inundation, but communities dominated by $P$. angustifolia were typically on surfaces with longer recurrence

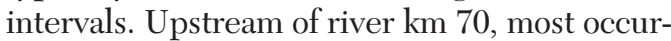
rences of $P$. angustifolia communities were on surfaces that have not been inundated by historic natural flows and would not be inundated by a flow with a recurrence interval of 150 years (Fig. 7). It is unknown how many of the occurrences of the $P$. angustifolia community would have been classified as riparian by Chapin et al. (2000). At least along the upper San Miguel River, however, $P$. angustifolia commonly occurs above the level of natural flooding by the river.

Most hydrologic gradient analyses of riparian vegetation relate species occurrence in small plots to hydraulic information derived by modeling a short reach of the river (Auble et al. 


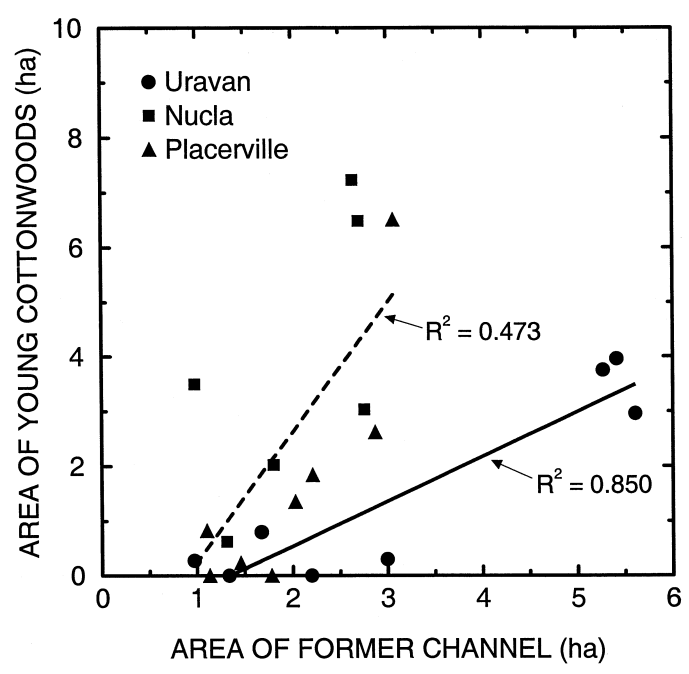

Fig. 8. Area of cottonwood reproduction in 1-km reaches along the San Miguel River as a function of the area of the former channel. Former channel consists of surfaces that were channel in the 1960s or 1982, but not in 1993. The area of cottonwood reproduction is the area of cottonwoods in age class "young" plus half of the area in age class "mixed-age." The 3 hydraulic reaches are indicated by circles (Uravan), squares (Nucla), and triangles (Placerville). The solid regression line is for Uravan, and the dashed regression line is for Nucla and Placerville combined. Species are Populus angustifolia James and Populus deltoides Marshall subsp. wislizenii (Watson) Eckenwalder.

1994). This approach allows precise quantification of the flow-vegetation relation for a small part of the river. Little knowledge is gained, however, about how this association varies along the river. Prediction of impacts of proposed changes in management may require the assumption that the small reach investigated accurately represents a much larger area. A strength of the present study is our use of data from long reaches of river representing diverse conditions. Achieving this broad coverage required us to sacrifice some precision. For example, because the mapped polygons are large, their inundation frequency cannot be as precisely specified as that of a small plot. In addition, although we had hydraulic information for 4 different reaches, it was still necessary to apply stage-discharge information from these hydraulic reaches to the longer inventory reaches, a process that introduced considerable error. Therefore, in this study we have traded local precision for a broader coverage to explore upstream variation in the relationship between flow and riparian vegetation.

\section{SuMmaRY AND CONCLUSIONS}

Plant communities along the San Miguel River were distinctly arrayed along the hydrologic gradient. The Salix exigua community occurred mostly on surfaces with a recurrence interval of inundation shorter than 2.2 years; Betula occidentalis and Alnus incana peaked on sites with recurrence intervals of inundation between 2.2 and 4.6 years. The hydrologic position occupied by communities dominated by Populus angustifolia was strongly related to the age of the trees and the species composition of the understory shrubs; young cottonwoods occurred at much shorter recurrence intervals than mature cottonwoods, and the $P$. angustifolia / S. exigua community occurred at much shorter recurrence intervals of inundation than the P. angustifolia / B. occidentalis and P. angustifolia / A. incana communities. Position of the cottonwood-dominated communities along the recurrence interval axis was drier than would be predicted on the basis of dominant understory species. For example, the $P$. angustifolia / S. exigua community occurred at longer recurrence intervals than the $S$. exigua community. This difference reflects the ability of $P$. angustifolia to overtop $S$. exigua, B. occidentalis, and A. incana on infrequently disturbed sites.

The fraction of riparian vegetation on surfaces historically inundated by the river decreased in the upstream direction from almost $100 \%$ near Uravan to below $50 \%$ along the South Fork of the San Miguel River. In upstream reaches a wetter climate reduces the reliance of riparian vegetation on water from the river, and much of the physical disturbance necessary to maintain riparian vegetation is provided by valley-side processes including debris flows, floods from minor tributaries, landslides, and beaver activity.

The observation that valley-side processes influence riparian vegetation is not new (Gregory et al. 1991, Chapin et al. 2000). Such processes, however, are often assumed to be unimportant relative to flow in the main stem. In the case of the upper San Miguel and South Fork San Miguel Rivers, valley-side processes may be the dominant influence on riparian vegetation along some reaches. Where vegetation is strongly influenced by valley-side processes, predictions of vegetation change based 
on analysis of changes in main stem flows (Auble et al. 1994, 2005) will be incomplete.

\section{ACKNOWLEDGMENTS}

This work was supported by the U.S. Geological Survey and the Bureau of Land Management. D. Paco VanSistine georegistered the aerial photography and digitized the geomorphic data. Jennifer Zoerner and Tom Stephens of the Colorado Natural Heritage Program mapped the vegetation types. Amanda Clements and Dennis Murphy initiated the study and reviewed a draft of the manuscript. Laura Perry, Michael Scott, and 2 anonymous referees provided constructive reviews.

\section{Literature Cited}

Allred, T.M., AND E.D. Andrews. 2000. Hydrology, channel characteristics, and sediment transport of the San Miguel River, southwest Colorado (USA). U.S. Geological Survey Water-Resources Investigations Report 00-4075, Boulder, CO.

Auble, G.T., J.M. Friedman, and M.L. ScotT. 1994. Relating riparian vegetation to present and future streamflows. Ecological Applications 4:544-554.

Auble, G.T., M.L. Scott, and J.M. Friedman. 2005. Use of individualistic streamflow-vegetation relations to assess impacts of flow alteration on wetland and riparian areas. Wetlands 25:143-154.

Auble, G.T., M.L. Scott, J.M. Friedman, J. Back, And V.J. LEE. 1997. Constraints on establishment of plains cottonwood in an urban riparian preserve. Wetlands 17:138-148.

BEDINGER, M.S. 1979. Forests and flooding with special reference to the White River and Ouachita River basins, Arkansas. U.S. Geological Survey, WaterResources Investigations Open File Report 79-68, Lakewood, CO.

Benda, L., N.L. Poff, D. Miller, G. Reeves, G. Pess, And M. POLLOCK. 2004. The network dynamics hypothesis: how channel networks structure riverine habitats. Bioscience 54:413-427.

Bendix, J. 1994. Scale, direction, and pattern in riparian vegetation-environment relationships. Annals of the Association of American Geographers 84:652-665.

Bradley, C.E., And D.G. Smith. 1986. Plains cottonwood recruitment and survival on a prairie meandering river floodplain, Milk River, southern Alberta and northern Montana. Canadian Journal of Botany 64: 1433-1442.

Campbell, C.J., and W.A. Dick-Peddie. 1964. Comparison of phreatophyte communities on the Rio Grande in New Mexico. Ecology 45:492-502.

Campbell, C.J., and W. Green. 1968. Perpetual succession of stream-channel vegetation in a semiarid region. Journal of the Arizona Academy of Science 5:86-98.

Chambers, J.C., R.J. Tausch, J.L. Korfmacher, D. GerMANOSKI, J.R. Miller, AND D. JewetT. 2004. Effects of geomorphic processes and hydrologic regimes on riparian vegetation. Pages 196-231 in J.C. Chambers and J.R. Miller, editors, Great Basin riparian ecosystems - ecology, management and restoration. Island Press, Washington, DC.

Chapin, D.M., R.L. Beschta, and H.W. Shen. 2000. Flood frequencies required to sustain riparian plant communities in the upper Klamath Basin, Oregon. Pages 17-22 in International Conference on Riparian Ecology and Management in Multi-Land Use Watersheds. American Water Resources Association, Middleburg, VA.

Cowles, H.C. 1901. The physiographic ecology of Chicago and vicinity: a study of the origin, development, and classification of plant societies. Botanical Gazette 31:73-108.

Day, R.T., P.A. Keddy, J. McNeill, and T. Carleton. 1988. Fertility and disturbance gradients: a summary model for riverine marsh vegetation. Ecology 69:1044-1054.

DeCamps, H., AND E. TABACCHI. 1994. Species richness in vegetation along river margins. Pages $1-20$ in P.S. Giller, A.G. Hildrew, and D.G. Raffaelli, editors, Aquatic ecology: scale pattern and process. Blackwell Scientific Publications, London.

Ellery, W.N., T.S. McCarthy, AND N.D. Smith. 2003. Vegetation, hydrology, and sedimentation patterns on the major distributary system of the Okavango Fan, Botswana. Wetlands 23:357-375.

FLeENER, G.B. 1997. Hydrologic and geomorphic aspects of riparian forest ecology on the lower San Miguel River, Colorado. Doctoral dissertation, University of Colorado, Boulder.

Follansbee, R., and L.R. SaWyer. 1948. Floods in Colorado. U.S. Geological Survey Water-Supply Paper 997, Reston, VA.

Franz, E.H., AND F.A. BAzZAZ. 1977. Simulation of vegetation response to modified hydrologic regimes: a probabilistic model based on niche differentiation in a floodplain forest. Ecology 58:176-183.

Friedman, J.M., AND G.T. Auble. 1999. Mortality of riparian box elder from sediment mobilization and extended inundation. Regulated Rivers: Research and Management 15:463-476.

Friedman, J.M., AND V.J. LeE. 2002. Extreme floods, channel change, and riparian forests along ephemeral streams. Ecological Monographs 72:409-425.

Friedman, J.M., W.R. Osterkamp, and W.M. Lewis, Jr. 1996. Channel narrowing and vegetation development following a Great Plains flood. Ecology 77: 2167-2181.

Gom, L.A., AND S.B. RooD. 1999. Patterns of clonal occurrence in a mature cottonwood grove along the Oldman River Alberta. Canadian Journal of Botany 77: 1095-1105.

Gregory, S.V., F.J. Swanson, W.A. McKee, and K.W. Cummins. 1991. An ecosystem perspective of riparian zones. BioScience 41:540-551.

Hansen, P.L., R.D. Pfister, K. Boggs, B.J. Cook, J. Joy, AND D.K. Hinckley. 1995. Classification and management of Montana's riparian and wetland sites. Montana Forest and Conservation Experiment Station Miscellaneous Publication 54, University of Montana, Missoula.

Hastings, J.R., and R.M. Turner. 1965. The changing mile. University of Arizona Press, Tucson.

Hedman, E.R., and W.R. Osterkamp. 1982. Streamflow characteristics related to channel geometry of streams in western United States. U.S. Geological Survey Water-Supply Paper 2193, Reston, VA. 
HupP, C.R. 1986. Upstream variation in bottomland vegetation patterns, northwestern Virginia. Bulletin of the Torrey Botanical Club 113:421-430.

Hupp, C.R., AND W.R. OsterKamp. 1985. Bottomland vegetation distribution along Passage Creek, Virginia, in relation to fluvial landforms. Ecology 66:670-681.

Jarkett, R.D. 1990. Paleohydrologic techniques used to define the spatial occurrence of floods. Geomorphology 3:181-195.

Johnson, R.R., AND C.H. LowE. 1985. On the development of riparian ecology. Pages 112-116 in R.R. Johnson, C.D. Ziebell, D.R. Patton, P.F. Ffolliott, and R.H. Hamre, technical coordinators, Riparian ecosystems and their management: reconciling conflicting uses. U.S. Department of Agriculture, Forest Service, General Technical Report RM-120.

JONGMAN, R.H.G., C.J.F. TER BRAAK, AND O.F.R. VAN TONGEREN. 1987. Data analysis in community and landscape ecology. Pudoc (Centre for Agricultural Publishing and Documentation), Wageningen, Netherlands.

Kittel, G., E. VanWie, M. Damm, R. Rondeau, S. KetTler, A. McMullen, and J. Sanderson. 1999. A classification of riparian wetland plant associations of Colorado: user guide to the classification project. Colorado Natural Heritage Program, Colorado State University, Fort Collins.

Malanson, G.P. 1993. Riparian landscapes. Cambridge University Press, New York.

Menges, E.S., AND D.M. WALLER. 1983. Plant strategies in relation to elevation and light in floodplain herbs. American Naturalist 122:454-473.

Naiman, R.J., R.E. BiLbY, and P.A. Bisson. 2000. Riparian ecology and management in the Pacific coastal rain forest. BioScience 50:996-1011.

Nilsson, C., A. Ekblad, M. Dynesius, S. Backe, M. Gardfjell, B. Carlberg, S. Hellqvist, and R. Jansson. 1994. A comparison of species richness and traits of riparian plants between a main river channel and its tributaries. Journal of Ecology 82:281-295.

Nilsson, C., G. Grelsson, M. Johansson, and U. Sperens. 1989. Patterns of plant species richness along riverbanks. Ecology 70:77-84.

Patten, D.T. 1998. Riparian ecosystems of semi-arid North America: diversity and human impacts. Wetlands 4: 498-512.

Primack, A.G.B. 2000. Simulation of climate-change effects on riparian vegetation in the Pere Marquette River, Michigan. Wetlands 20:538-547.
Robertson, P.A., G.T. Weaver, and J.A. Cavanaugh. 1978. Vegetation and tree species patterns near the northern terminus of the southern floodplain forest. Ecological Monographs 48:249-267.

Rot, B.W., R.J. Naiman, and R.E. Bilby. 2000. Stream channel configuration, landform, and riparian forest structure in the Cascade Mountains, Washington. Canadian Journal of Fisheries and Aquatic Sciences 57:699-707.

Scott, M.L., G.T. Auble, and J.M. Friedman. 1997. Flood dependency of cottonwood establishment along the Missouri River, Montana, USA. Ecological Applications 7:677-690.

Surian, N., AND E.D. ANDrEws. 1999. Estimation of geomorphically significant flows in alpine streams of the Rocky Mountains, Colorado (USA). Regulated Rivers: Research and Management 15:273-288.

Valenciano, D. 1992. Elevational and cross-sectional gradients in montane riparian plant communities of subMogollon Arizona: a comparison to adjacent upland communities. Master's thesis, Arizona State University, Tempe.

WASKLEWICZ, T.A. 2001. Riparian vegetation variability along perennial streams in central Arizona. Physical Geography 22:361-375.

Webb, G.M., AND J.D. Brotherson. 1988. Elevational changes in woody vegetation along three streams in Washington County, Utah. Great Basin Naturalist 48:512-529.

WELLS, J.V.B. 1954. Compilation of records of surface waters of the United States through September 1950; Part 9, Colorado River Basin. U.S. Geological Survey Water-Supply Paper 1313, Reston, VA.

WhitTaker, W.H. 1956. Vegetation of the Great Smoky Mountains. Ecological Monographs 26:1-80.

1967. Gradient analysis of vegetation. Biological Reviews 49:207-264.

Williams, P.L. 1964. Geology, structure, and uranium deposits of the Moab Quadrangle, Utah and Colorado. U.S. Geological Survey Miscellaneous Investigations Series Map I-360, scale 1:250,000.

Zimmerman, R.C. 1969. Plant ecology of an arid basin, Tres Alamos-Redington area southeastern Arizona. U.S. Geological Survey Professional Paper 485-D, Reston, VA.

Received 3 November 2003 Accepted 6 April 2005 